\title{
Hybridization between European and Africanized honeybees in tropical Yucatan, Mexico. II. Morphometric, allozymic and mitochondrial DNA variability in feral colonies
}

\author{
José Javier G. QUEZADA-EuÁN* \\ Facultad de Medicina Veterinaria y Zootecnia, Universidad Autónoma de Yucatán, \\ Apdo. Postal 4-116, Mérida, Yucatan 97100, Mexico \\ (Received 10 December 1998; revised 11 January 2000; accepted 24 January 2000)
}

\begin{abstract}
This paper presents the results of a long-term study on the genetic status of feral Yucatecan honey bees combining analyses of morphological, allozyme and mitochondrial DNA (mtDNA) characters. The results showed that feral Yucatecan colonies had varying degrees of association between European/African morphology, allozymes and haplotypes. Frequencies of European markers varied between years, but markers (polymorphisms) of European origin were present in the Yucatecan feral population in frequencies that indicate a process of European/African hybridization. These data suggest that population size, environmental conditions and characteristics of the established feral population in Yucatan have provided quantitative and qualitative opportunities for European gene introgression in the feral population, and thus better explain the present genetic composition of feral Africanized honeybees in southeast Mexico.
\end{abstract}

Apis mellifera / Africanized honeybee / hybridization / mtDNA / morphology / allozyme / Yucatan

\section{INTRODUCTION}

In contrast to other parts of Mexico, the European honey bees, Apis mellifera L., were not imported into Yucatan until the early 1900s. These bees were introduced directly from the United States in the form of queen breeding stock, mostly consisting of the east-European subspecies A. m. caucasica and $A$. $m$. ligustica [1]. Fifty years later, a prosperous beekeeping industry had developed in this region of Mexico, with

* Correspondence and reprints

E-mail: qeuan@tunku.uady.mx 
one of the largest concentrations of managed colonies of honeybees in the world. The density before 1987 was 17 hives of European colonies per square kilometre [29]. As in other areas of the neotropics, European honeybees never established feral populations in Yucatan.

Africanized feral honeybees (descendants of A. m. scutellata) were first reported in the Yucatan Peninsula in 1987 [26]. Populations of these bees spread throughout the American tropics. This expansion began with the accidental escape of 26 African swarms from an experimental apiary in Brazil 30 years before [13].

The genetic status of Africanized honeybees remains controversial [34]. Basically, the process of Africanization is regarded as an asymmetrical one [28], but whether African/European asymmetries arise from: (i) genetic incompatibilities, or (ii) competitive advantages of Africanderived bees, is not clear. The extensive European resident population in the Yucatan provides an ideal site to evaluate gene flow between managed colonies and feral African colonies, and to test hypotheses on the parentage of Africanized bees.

The diverse arrangement of morphotyes [26], mitotypes [29] and behaviour [25] provides evidence of an extensive process of hybridization in the Yucatecan-managed population.

Little information has been obtained, however, on the genetic status of the currently established feral Yucatecan population of honeybees [23]. In a preliminary study, Quezada-Euán and Hinsull [22] found a diverse arrangement of morphotype/mitotype associations, which suggested that a European gene flow occurred in the feral population during the early stages of Africanization, probably as a consequence of the high densities of European resident-managed colonies. These results are in contrast with what has been found in other areas of the neotropics [8, 35]. However, the persistence of hybrids with European markers in feral populations has not been reported; this is necessary when considering the relative importance of population size in the contribution of European genes to the feral pool in the neotropics.

In this paper, the results are presented of a long-term study on the frequencies of European phenotypic and genetic markers in the Yucatecan population of feral honeybees.

\section{MATERIALS AND METHODS}

A long-term population analysis of honeybees from Yucatan included samples collected annually between 1988 and 1998 from both feral and managed colonies (see [26]). Fifteen localities were routinely sampled every year.

Feral colonies were located in 1988 , 1990, 1992, 1993, 1994 and 1996. Colonies were mainly found with the help of local beekeepers. Some colonies were also collected from cardboard swarm traps provided by the Mexican Ministry of Agriculture (SAGAR). Samples of adult workers were collected live from each feral colony, and then either stored in ethanol (99\%) for mitochondrial DNA (mtDNA) and morphometric studies or frozen in liquid nitrogen for later allozyme analysis.

\subsection{Morphometric analysis}

Ten bees from each sample were dissected, and four anatomical parts from each were mounted on slides. Twenty-five morphometric characters were measured for each bee in accordance with the method of Daly and Balling [3], using an inverted microscope (Indumex), a digitizing tablet (Summasketch II) and a PC. Samples collected in 1988 were only submitted to the Daly and Balling [3] level 4 discriminant function analysis. After measuring samples, they were assigned a probability of Africanization (PA), calculated by the Daly and 
Balling functions [3] and the AFUSDA programme [30]. PAs were used to classify colonies in accordance with the categories of Rinderer et al. [30], as modified by Quezada-Euán et al. [23], i.e.: Africanized (A), Africanized with evidence of European introgression (AE); European with evidence of African introgression (EA); and European $(\mathrm{E})$.

\section{2. mtDNA analysis}

Polymorphisms at two restriction sites were studied in mitochondria of feral Yucatecan colonies. Samples collected in 1988 and 1992 were analyzed at the ls RNA region. The presence/absence of an EcoRI restriction site is a diagnostic indicator, and enables the separation of African and eastEuropean honeybees [9].

The $B g l$ II restriction site of the cytochrome $b$ region was analyzed in samples from 1990, 1993, 1994 and 1996. The BglII region remains uncleaved in Africanized bees, and produces 291 and 194 bp fragments in non-Africanized bees [2]

mtDNA was extracted from one worker bee in accordance with the procedure of Moritz et al. [19], and amplification via polymerase chain reaction (PCR) was carried out following the method of Saiki et al. [32]. The PCR temperature profile was performed as described by Hall and Smith [9].

Ten microlitre aliquots of PCR product were digested with either 3 units of EcoRI or $B g l$ II (Boehringer) for $3 \mathrm{~h}$. The total digestion volume was loaded onto $1.5 \%$ agarose gel and electrophoresed using TBE buffer at $90 \mathrm{~V}$ for $3 \mathrm{~h}$. The gels were stained with ethidium bromide and photographed over a UV light source.

\subsection{Allozyme analysis}

The variant forms of malate dehydrogenase (Mdh) and hexokinase (Hk) were analyzed in feral colonies collected in 1996 only. The Mdh-1 locus has 3 variants, with the $\mathrm{Mdh}^{1.00}$ allele being more frequent in African colonies [20]. The Hk-1 locus has 3 variants, with the $\mathrm{Hk}^{1.00}$ allele being nearly fixed in European bees [4].

Homogenates from individual bees were run on polyacrylamide mini-gels using the isoelectric focussing technique in a minicell (Bio-Rad). The electrophoretic conditions were in accordance with the manufacturer's recommendations. Staining conditions were in accordance with the protocols of Hung and Rubink (1992).

Allozyme variants were scored by their relative mobilities on the gels. Allele frequencies were calculated for each system and were then compared with the allele frequencies reported for feral colonies in Brazil [33] and Costa Rica [14] by means of a $\chi^{2}$ test.

\section{RESULTS}

The haplotypic and morphotypic frequencies of feral colonies are presented in Figures 1 and 2 respectively.

One year after the Africanization process had begun in Yucatan (1988), all 5 feral colonies analyzed for mtDNA showed A haplotypes; $100 \%$ of the 10 feral colonies morphometrically analyzed the same year were also A. Two years later (1990), a significant reduction in the percentage of morphometrically classified A colonies was observed in the feral population; out of 15 colonies collected, $80 \%$ were identified as having pure A morphology, $13 \%$ as $\mathrm{AE}$, and $6 \%$ as EA. Thirteen of these colonies (87\%) had A haplotypes and 2 had E haplotypes.

The lowest percentage of morphometrically classified A feral colonies was obtained in 1992, with only $58 \%$ of colonies classified as A. A significant increase in the percentage of E haplotypes (20\%) accompanied the decrease in A morphotypes observed that year. 


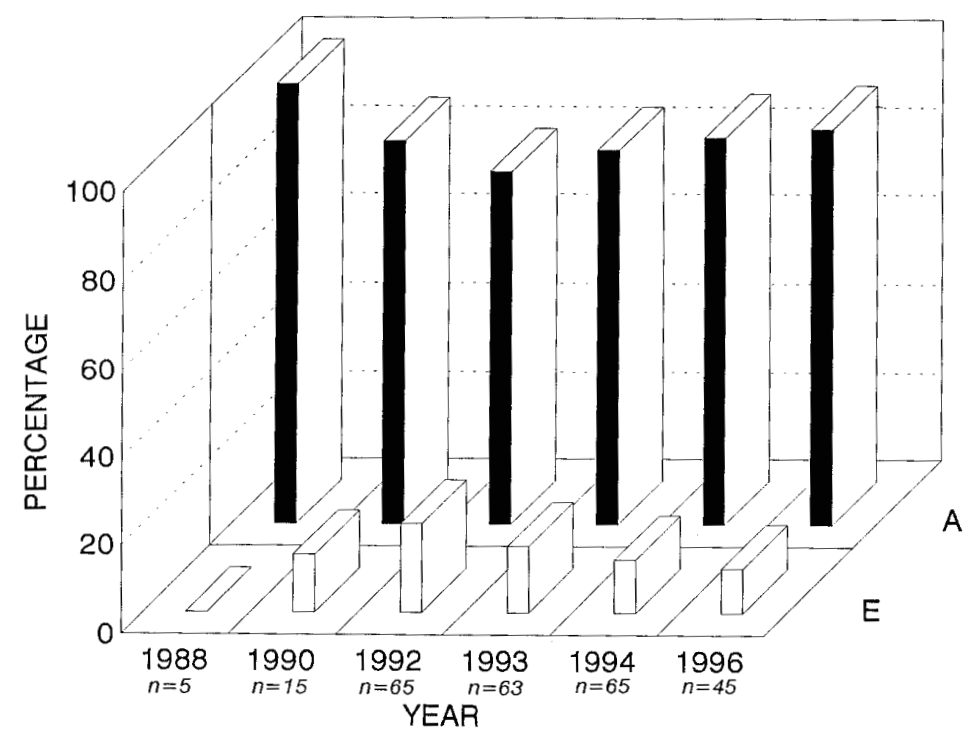

Figure 1. Annual haplotype frequencies (A: African; E: European) in Yucatecan feral honeybees.

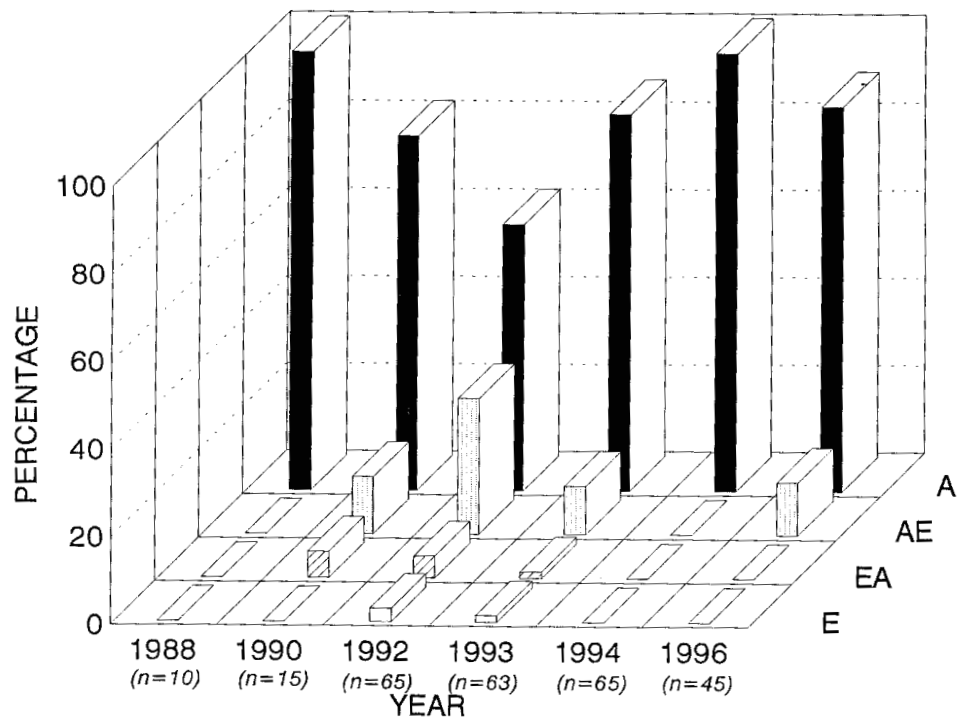

Figure 2. Annual morphotype frequencies in Yucatecan feral honeybees in accordance with the analysis of Rinderer et al. [30].

In subsequent years, a constant increase was observed in the percentage of morphometrically classified A colonies: 86\% (1993); $100 \%$ (1994) and $88 \%$ (1996). Interestingly, by $1996,11 \%$ of the feral colonies were still morphometrically classified as AE.
A similar pattern to that of morphometrics was observed in the frequencies of haplotypes between 1993 and 1996. The African haplotype increased between $1993(85 \%)$ and $1996(91 \%)$. However, it in interesting to note that 10 years after the start of the 
Africanization process in Yucatan, there were still feral colonies (9\%) with European haplotypes.

The association of morphotype/haplotype is presented in Tables I and II. It is evident that most feral colonies were of African haplotype/morphotype in all the years of study. For instance, in 1992 when the larger proportion of European haplotypes was found in feral colonies, the value of the haplotype/morphotype association was 8.264 $(P>0.01)$ (after a $G$-test with William's correction). Nevertheless, it was also evident that the feral population showed no evidence of European gene introgression in 1988, but that it had European genes in subsequent years after their arrival in the Yucatan.

The results of the allozyme analysis showed that the Mdh ${ }^{.63}$ and the Mdh ${ }^{0.53}$ alleles were not present in a high proportion of feral bees in 1996 (frequencies of 0.12 and 0.04 respectively). However, the frequency of the $\mathrm{Hk}^{1.00}$ allele, which is reported to be fixed in European bees, was found in a significant percentage of feral colonies (Tab. III).

The frequency of the 'African' Mdh ${ }^{1.00}$ found in feral Yucatecan colonies in 1996 was not significantly different to that in feral populations from Brazil $\left(\chi_{(0.01,5 \mathrm{gl})}^{2}=15.09>\right.$ 12.6) and Costa Rica $\left(\chi_{(0.01,5 \mathrm{gl})}^{2}=15.09>\right.$ 0.9 ; see Tab. III). The frequency of the
'European' $\mathrm{Hk}^{1.00}$ allele was comparatively (but not significantly) higher in feral Yucatecan colonies than that reported in feral populations from Brazil $\left(\chi^{2}(0.01,2 \mathrm{gl})=9.21>\right.$ 6.65) and Costa Rica $\left(\chi^{2}{ }_{(0.01,2 \mathrm{gl})}=9.21>\right.$ 0.98 ; see Tab. III). Recent evidence has questioned the use of Mdh as a genetic marker, since it is not selectively neutral [11]. Therefore it is not rare to find high frequencies of $\mathrm{Mdh}^{1.00}$ in feral Yucatecan populations. However, the evidence from the Hk allelic frequencies showed that $31(69 \%)$ colonies were heterozygous for the $\mathrm{Hk}^{1.00}$ and $\mathrm{Hk}^{0.87}$ alleles. Additionally, 7 (16\%) colonies that were homozygous for the 'European' $\mathrm{Hk}^{1.00}$ allele had an African morphotye and haplotype. These findings were in agreement with the analyses of morphotype and haplotype, i.e., that feral Yucatecan honeybees show evidence of an admixture of European/African genes.

\section{DISCUSSION}

The feral colonies in this study showed evidence of much introgression of European genes, even 10 years after the first report of an Africanized feral colony in the Yucatan. In contrast, the first feral colonies collected from this region of Mexico in 1988 seemed to have practically no evidence of European gene introgression, but 5 years later and onwards the presence of European genes

Table I. Haplotypes and morphotypes in Yucatecan feral colonies across the years of study (A: African; E: European; AE: African with evidence of introgression of European genes; EA: European with evidence of introgression of African genes).

\begin{tabular}{|c|c|c|c|c|c|c|c|c|c|c|c|c|}
\hline \multirow{3}{*}{$\begin{array}{l}\text { Haplotype } \\
\text { Morphotype }\end{array}$} & \multicolumn{12}{|c|}{ Year } \\
\hline & \multicolumn{2}{|c|}{1988} & \multicolumn{2}{|c|}{1990} & \multicolumn{2}{|c|}{1992} & \multicolumn{2}{|c|}{1993} & \multicolumn{2}{|c|}{1994} & \multicolumn{2}{|c|}{1996} \\
\hline & A & $\mathrm{E}$ & A & $\mathrm{E}$ & A & $\mathrm{E}$ & A & $\mathrm{E}$ & A & $\mathrm{E}$ & A & $\mathrm{E}$ \\
\hline A & 5 & 0 & 11 & 1 & 34 & 4 & 47 & 6 & 57 & 8 & 39 & 2 \\
\hline $\mathrm{AE}$ & 0 & 0 & 1 & 1 & 14 & 6 & 6 & 3 & 0 & 0 & 2 & 2 \\
\hline EA & 0 & 0 & 1 & 0 & 4 & 1 & 1 & 0 & 0 & 0 & 0 & 0 \\
\hline E & 0 & 0 & 0 & 0 & 0 & 2 & 0 & 0 & 0 & 0 & 0 & 0 \\
\hline
\end{tabular}


Table II. Haplotype, morphotype and allozyme frequencies for Yucatecan feral colonies collected in 1996.

\begin{tabular}{|c|c|c|c|c|c|c|c|}
\hline Colony & Morphotype & Haplotype & $\mathrm{Hk}^{1.00}$ & $\mathrm{Hk}^{0.87}$ & $\mathrm{Mdh}^{1.00}$ & $\mathrm{Mdh}^{0.63}$ & $\mathrm{Mdh}^{0.53}$ \\
\hline 1 & A & A & 2 & 0 & 1 & 1 & 0 \\
\hline 2 & A & A & 1 & 1 & 0 & 1 & 1 \\
\hline 3 & A & A & 2 & 0 & 2 & 0 & 0 \\
\hline 4 & A & A & 1 & 1 & 2 & 0 & 0 \\
\hline 5 & A & $\mathrm{A}$ & 1 & 1 & 2 & 0 & 0 \\
\hline 6 & A & A & 1 & 1 & 2 & 0 & 0 \\
\hline 7 & A & $\mathrm{A}$ & 1 & 1 & 2 & 0 & 0 \\
\hline 8 & A & A & 1 & 1 & 2 & 0 & 0 \\
\hline 9 & A & A & 0 & 2 & 2 & 0 & 0 \\
\hline 10 & A & A & 1 & 1 & 2 & 0 & 0 \\
\hline 11 & A & A & 0 & 2 & 2 & 0 & 0 \\
\hline 12 & A & $\mathrm{A}$ & 0 & 2 & 0 & 1 & 1 \\
\hline 13 & A & A & 0 & 2 & 1 & 1 & 0 \\
\hline 14 & A & A & 1 & 1 & 1 & 1 & 0 \\
\hline 15 & A & A & 1 & 1 & 1 & 1 & 0 \\
\hline 16 & A & A & 1 & 1 & 1 & 1 & 0 \\
\hline 17 & A & A & 2 & 0 & 1 & 1 & 0 \\
\hline 18 & A & A & 2 & 0 & 2 & 0 & 0 \\
\hline 19 & A & A & 1 & 1 & 2 & 0 & 0 \\
\hline 20 & A & A & 1 & 1 & 2 & 0 & 0 \\
\hline 21 & A & A & 2 & 0 & 2 & 0 & 0 \\
\hline 22 & A & A & 2 & 0 & 2 & 0 & 0 \\
\hline 23 & A & A & 1 & 1 & 2 & 0 & 0 \\
\hline 24 & A & A & 1 & 1 & 2 & 0 & 0 \\
\hline 25 & A & $\mathrm{A}$ & 1 & 1 & 2 & 0 & 0 \\
\hline 26 & A & A & 1 & 1 & 2 & 0 & 0 \\
\hline 27 & A & A & 1 & 1 & 2 & 0 & 0 \\
\hline 28 & A & A & 1 & 1 & 2 & 0 & 0 \\
\hline 29 & A & A & 1 & 1 & 2 & 0 & 0 \\
\hline 30 & A & A & 1 & 1 & 2 & 0 & 0 \\
\hline 31 & A & A & 1 & 1 & 2 & 0 & 0 \\
\hline 32 & A & A & 1 & 1 & 2 & 0 & 0 \\
\hline 33 & A & A & 1 & 1 & 2 & 0 & 0 \\
\hline 34 & A & A & 1 & 1 & 2 & 0 & 0 \\
\hline 35 & $\mathrm{~A}$ & A & 2 & 0 & 2 & 0 & 0 \\
\hline 36 & A & $\mathrm{A}$ & 1 & 1 & 2 & 0 & 0 \\
\hline 37 & A & $\mathrm{A}$ & 1 & 1 & 2 & 0 & 0 \\
\hline 38 & A & A & 1 & 1 & 2 & 0 & 0 \\
\hline 39 & A & A & 1 & 1 & 2 & 0 & 0 \\
\hline 40 & A & $\mathrm{E}$ & 1 & 1 & 2 & 0 & 0 \\
\hline 41 & A & $\mathrm{E}$ & 0 & 2 & 1 & 0 & 1 \\
\hline 42 & $\mathrm{AE}$ & A & 2 & 0 & 0 & 1 & 1 \\
\hline 43 & $\mathrm{AE}$ & A & 1 & 1 & 1 & 1 & 0 \\
\hline 44 & $\mathrm{AE}$ & $\mathrm{E}$ & 1 & 1 & 2 & 0 & 0 \\
\hline 45 & $\mathrm{AE}$ & $\mathrm{E}$ & 2 & 0 & 1 & 1 & 0 \\
\hline
\end{tabular}

Allozyme frequencies are expressed as the number of allele types in the same worker bee. 
Table III. Mdh and Hk frequencies found in feral Yucatecan honeybees and reported frequencies in feral populations from Brazil and Costa Rica.

\begin{tabular}{lccccc}
\hline & Mdh $^{1.00}$ & Mdh $^{0.63}$ & Mdh $^{0.53}$ & $\mathrm{Hk}^{1.00}$ & $\mathrm{Hk}^{0.87}$ \\
\hline Yucatán 1996 & 0.833 & 0.120 & 0.046 & 0.540 & 0.460 \\
Brazil & $0.78^{1}$ & $0.18^{1}$ & $0.04^{1}$ & $0.449^{2}$ & $0.549^{2}$ \\
Costa Rica $^{3}$ & 0.827 & 0.128 & 0.045 & 0.505 & 0.495 \\
\hline
\end{tabular}

${ }^{1}[33] ;{ }^{2}[4] ;{ }^{3}[14]$.

has been clear in feral bees. A plausible explanation for these findings is that 'in situ' hybridization of a migrant population of almost pure African genetic make-up has occurred in the Yucatan Peninsula. This situation strongly contrasts with reports from other latitudes in the neotropics, where minimal evidence of introgression of European genes has been found in feral colonies [8, 35].

The lack of European genes in feral populations of honeybees has been attributed to asymmetric gene flow, possibly due to genetic incompatibilities in hybrids between the two strains [10], but also to population size differences between resident European colonies and invading Africanized colonies $[21,29]$. The present results of this longterm study on feral Yucatecan honeybees suggest that it is more likely that the high density of commercial European colonies has influenced the genetic make-up of feral colonies during the process of Africanization in Yucatan. Although there was a high frequency of African mtDNA in Yucatecan feral colonies, this finding could be explained by differences in the reproductive behaviour of Africanized bees with respect to their European counterparts [21]. For instance, the high reproductive rate of colonies headed by Africanized queens might eventually lead to a reduction of European genes in the feral pool simply by a numerical (selective) effect, rather than as a result of genetic incompatibilities [14, 21]. However, it was also evident that European mtDNA was present in a significant proportion of feral colonies, which indicates the contribution of European maternal lines to the feral pool.

It has been suggested that European genes might confer a biological disadvantage for colony survival in the tropics, and that under natural selection such colonies might be removed at faster rates than colonies of purer African composition [7]. However, high population densities of managed European colonies can probably create a scenario in which European genes may have a better chance of introgression and survival in the feral Africanized pool [14, 18, 21]. In Yucatan at the start of the Africanization process, European colonies were at a numerical advantage and this situation probably created the conditions for a high degree of introgression of European genes within the feral population. Simultaneously, the presumed biological advantages of Africanized colonies in tropical climates may result in the disappearance, albeit seemingly slow, of European markers in the feral population.

As the present data suggest, hybridization between Africanized/European colonies in the tropics can occur provided sufficient European colonies exist in an area to counterbalance the rapid population growth of Africanized colonies [31]. A common scenario in South and Central American countries has been a complete and rapid elimination of managed European colonies with little introgression of European markers in the feral gene pool [7, 28]. South American countries had very small resident European populations compared with the large 
commercial populations found in SE Mexico. In this context, European genetic markers would be expected to be rare if the feral population had resulted from a rapid and intense expansion of Africanized colonies [21]. In Venezuela, for example, there were only ca. 40000 colonies of European bees in 1976, just before the start of Africanization [36]. Today the reported feral population probably reaches 2 million colonies [21].

Recent studies also provide support for the hypothesis that variation in European gene introgression in feral populations has been due to numerical differences between managed European colonies and feral Africanized colonies. For instance in Brazil, Sheppard et al. [33] reported a significant polymorphism of European origin persisting in the feral population in the region near the historic start of Africanization. In Costa Rica, Lobo [14] reported different gene frequencies of mitochondrial and nuclear European genetic markers in feral honeybees, probably resulting from different selection pressures among colonies with African and European queens.

An additional explanation for a significant introgression of European genes in the feral Yucatecan population may be found in the environmental conditions of this area of Mexico. The Yucatan's original rain forest has been largely replaced by secondary vegetation resulting from an intense deforestation since the beginning of this century. Nowadays less than $15 \%$ of the original forest remains unaltered [17]. This situation has probably created an ideal environment for the growth of Yucatan's important nectar-secreting vegetation, and thus for commercial beekeeping [6]. But on the other hand, the same conditions have probably affected the nesting opportunities of native social bees [5] and probably of feral honeybee colonies. In a survey of feral colonies in Yucatan, Quezada-Euán and May-Itza [23] estimated an average of 25 honeybee colonies per $\mathrm{km}^{2}$ of relatively undisturbed habitat; but this figure may be much lower in disturbed areas. Additionally, nowadays many beekeepers collect feral colonies to incorporate into their apiaries which are often not requeened [5], and this practice may constantly act in reducing the numbers and excessive growth of colonies in the wild but increasing the frequencies of African haplotypes in the managed population [24]. Thus, the high densities of feral colonies reported in other neotropical sites may not be applicable to the Yucatan, and thus the probability of European gene introgression may be higher.

Another explanation for the present findings may rely on the different genetic characteristics of colonies at the Africanized invasion front and those in the feral population that eventually become established in a given area. Ratnieks [27] suggests that the invasion front may be composed of colonies selected for their colonizing ability, and therefore African/European hybrid colonies with a comparatively lower colonizing ability would be left behind the invasion front. Therefore, if only colonies at the invasion front were analyzed, the probability of finding European genes would be reduced by the different rate of selection of European genes in colonizing bees. Feral swarms arriving behind the colonizing front more likely possess and/or accept the introgression of European genes, presumably due to a lower colonizing ability. In fact, the lack of European genes in feral Yucatecan colonies sampled in 1988 compared to colonies sampled at later dates supports this hypothesis.

Probably a combination of all these factors has played a role in determining that 10 years after the arrival of Africanized honeybees in Yucatan, feral colonies in this area of Mexico still show evidence of mixed European/African composition, as indicated by morphological, isozymic and DNA markers. This evidence suggests that introgressive hybridization rather than complete replacement is the most parsimonious hypothesis to explain Africanization in Yucatan, most likely due to the presence of a large population of resident European bees. 
Résumé - Hybridation entre les abeilles domestiques européennes et africaines (Apis mellifera L.) dans le Yucatan, Mexique. II. Variabilité morphologique, allozymique et de l'ADNmt dans des colonies sauvages. Les abeilles domestiques européennes élevées dans le Yucatan, Mexique, sous le climat sub-tropical ont subi dix ans de mélange génétique avec les colonies de descendance africaine. Leur état d'hybride a été maintes fois documenté [24, 26]. Il n'est pourtant pas clair que la forte densité d'abeilles européennes élevées au Yucatan ait eu une influence génétique sur la population sauvage récemment établie et censée être principalement africanisée [22, 29]. Cet article présente les résultats d'une étude à long terme sur le statut génétique des abeilles des colonies sauvages du Yucatan réalisée à l'aide de l'analyse combinée des caractères morphométriques, allozymiques et de l'ADN mitochondrial. Des colonies sauvages ont été récoltées en 1988, 1990, 1992, 1993, 1994 et 1996. Une probabilité d'africanisation (PA), calculée à l'aide des fonctions discriminantes morphométriques de Daly et Balling [3] et par un programme de morphométrie [30], a été attribuée à chaque échantillon. Les PA ont été utilisées pour classer les colonies en fonction des catégories de Rinderer et al. [30] et de Quezada-Euán et May-Itza [23]. En outre les polymorphismes des fragments de restriction de l'ADNmt sur les sites de coupure des enzymes EcoRI et BglII ont été étudiés [2,9]. Les formes déviantes de la malate déshydrogénase $(M d h)$ et de l'hexokinase $(H k)$ n'ont été analysées que dans les colonies sauvages récoltées en 1996. Les résultats montrent que les colonies sauvages du Yucatan présentent divers degrés d'association entre les caractères morphologiques, les caractères allozymiques et les haplotypes européens et africains. Les fréquences des marqueurs européennes varient d'une année à l'autre, mais les marqueurs européens ou les polymorphismes sont présents dans la population sauvage pour toutes les années étudiées, indiquant un processus d'hybridation entre abeilles européennes et abeilles africaines. La comparaison des fréquences allozymiques avec celles du Brésil et du Costa-Rica a également montré que les loci européens étaient présents dans les colonies sauvages du Yucatan avec une fréquence supérieure. Ces données suggèrent que la taille de la population, les conditions du milieu et les caractéristiques de la population sauvage établie au Yucatan ont fourni des occasions quantitatives et qualitatives à l'introgression de gènes européens dans la population sauvage. On a ainsi une meilleure explication de la composition génétique actuelle des abeilles sauvages africanisées du sud-ouest du Mexique.

\section{Apis mellifera / abeille africanisée / hybri- dation / morphologie / allozyme / ADNmt / Yucatan}

Zusammenfassung - Hybridisierung europäischer und afrikanisierter Honigbienen im tropischen Yukatan, Mexiko. II. Morphometrische, allozymatische und mtDNA Variabilität in wildlebenden Völkern. Die bewirtschafteten europäischen Honigbienen im subtropischen Yukatan, Mexiko waren über einen Zeitraum von 10 Jahren einer genetischen Vermischung mit Völkern afrikanischer Herkunft ausgesetzt. Ihre Hybridisierung ist vielfach belegt worden [24, 26]. Es ist allerdings unklar, ob es einen genetischen Einfluss der in hoher Dichte in Yukatan gehaltenen europäischen Völker auf die neuerdings etablierte Wildpopulation gibt, von der angenommen wird dass sie primär afrikanisiert ist [22, 29]. In diesem Artikel werden die Ergebnisse einer langjährigen Studie zum genetischen Status der Wildpopulation von Honigbienen in Yukatan dargestellt. Die Untersuchung schlie $\beta$ t morphologische, allozymatische und mtDNA-Merkmale ein. Wildlebende Völker wurden 1988, 1990, 1992, 1993, 
1994 und 1996 besammelt. Den Proben wurde unter Verwendung der morphometrischen Diskriminanzfunktion von Daly und Balling [3] und einem morphometrischen Programm [30] eine Afrikanisierungswahrscheinlichkeit (PA) zugeordnet, nach der sie in Übereinstimmung mit den Kriterien von Rinderer et al. [30] und Quezada-Euán et al. [23] klassifiziert wurden. Zusätzlich wurden Polymorphismen der mtDNA-Restriktionsfragmente der Enzymeschnittstellen EcoRI und BglII untersucht $[2,9]$. Schlussendlich wurden abweichende Formen der Malat-Dehydrogenase (Mdh) und der Hexokinase (Hk) von 1996 besammelten Völkern bestimmt. Die Ergebnisse zeigen, dass die wildlebenden Völker Yukatans ein unterschiedliches Ausmass der Vermischung europäischer und afrikanischer morphologischer, allozymatischer Merkmale sowie der DNA-Haplotypen zeigten. Die Häufigkeit der europäischen Marker war in den verschiedenen Jahren unterschiedlich, allerdings traten in allen Jahren, in denen die wildlebende Population Yukatans untersucht worden war, europäische Marker oder Polymorphismen auf und belegten damit einen europäisch-afrikanischen Hybridisierungsprozess. Der Vergleich der Allozymhäufigkeit mit der in Brasilien und Costa Rica deutete hierbei auf einen höheren Anteil europäischer Loci in der Wildpopulation von Yukatan hin. Nach diesen Erhebungen hätten Populationsgröße, Umweltbedingungen und Eigenschaften der etablierten Wildpopulation von Yukatan quantitative und qualitative Gelegenheiten für das Eindringen europäischer Gene in die Wildpopulation geboten; dies würde die derzeitige genetische Zusammensetzung der wildlebenden Honigbienenpopulation in Südostmexiko besser erklären.

\section{Apis mellifera / afrikanisierte Honigbiene / Hybridisierung / mtDNA / Morphologie / Allozym / Yukatan}

\section{ACKNOWLEDGMENTS}

The author is most thankful to the IFS (Sweden) and CONACyT (Mexico) for the grants provided to conduct this research. Sincere thanks are expressed to Robert J. Paxton, who made useful suggestions regarding a first draft of this manuscript, to Sue M. Hinsull for her support during the laboratory work at the University of Wales in Cardiff, to Akey C.F. Hung and Glenn W. Freeman for their advice during the isozyme analyses, and to William L. Rubink for the copy of his morphometrics programme. Finally, the author wishes to acknowledge the assistance of all those persons and students who helped him during his field and laboratory work over the last 10 years.

\section{REFERENCES}

[1] Calkins C.F., Beekeeping in Yucatan: a study in historical-cultural zoogeography, Ph.D. diss. Univ. Nebraska, NE, USA, 1974.

[2] Crozier Y.C., Coulianos S., Crozier R.H., An improved test for Africanized honeybee mitochondrial DNA, Experientia 47 (1991) 968-969.

[3] Daly H.V., Balling S.S., Identification of Africanized honey bees in the western hemisphere by discriminant analysis, J. Kans. Entomol. Soc. 51 (1978) 857-869.

[4] Del Lama M.A., Figueredo R.A., Soares A.E.E. Del Lama S.N., Hexokinase polymorphism in Apis mellifera and its use for Africanized honey bee identification, Rev. Bras. Genet. 11 (1988) 287-297.

[5] Echazarreta C.M., Quezada-Euán J.J.G., Medina M.L., Pasteur K.L., Beekeeping in the Yucatan Peninsula: development and current status, Bee World 78 (1977) 115-127.

[6] Flores J.S., Importancia de la zona henequenera en la producción de miel, in: Peniche P., Santamaria F. (Eds.), Memorias de la conferencia nacional sobre el henequén y la zona henequenera, Arch. Gen. Gobierno de Yucatán, UADY-INIFAP, Mexico, 1993, pp. 113-116.

[7] Hall H.G., DNA studies reveal processes involved in the spread of new world African honeybees, Fla. Entomol. 75 (1992) 51-59.

[8] Hall H.G., Muralidharan K., Evidence from mitochondrial DNA that African honey bees spread as continuous maternal lineages, Nature 339 (1989) 211-213

[9] Hall H.G., Smith D.R., Distinguishing African and European honeybee matrilines using amplified mitochondrial DNA, Proc. Natl. Acad. Sci. USA 88 (1991) 4548-4552.

[10] Harrison J.F., Hall H.G., African-European honeybee hybrids have low intermediate metabolic capacities, Nature 363 (1993) 258-259. 
[11] Hatty S., Oldroyd B.P., Evidence for temperature dependent selection for malate dehydrogenase allele frequencies in honey bee populations, J. Hered. (1999) in press.

[12] Hung A.C.F., Rubink W.L., Crewe R.M., Association of enzyme/protein loci in individual honey bees (Apis mellifera L.) (Hymenoptera: Apidae), BeeScience 1 (1991) 225-229.

[13] Kerr W.E., The history of the introduction of Africanized bees in Brazil, S. Afr. Bee J. 39 (1967) 3-5.

[14] Lobo J.A., Morphometric, isozymic and mitochondrial variability of Africanized honeybees in Costa Rica, Heredity 75 (1995) 133-141.

[15] Lobo J.A., Krieger H., Maximum likelihood estimates of gene frequencies and racial admixture in Apis mellifera L. (Africanized honey bees), Heredity 68 (1992) 441-448.

[16] Lobo J.A., Del Lama M.A., Mestriner M.A., Population differentiation and racial admixture in the Africanized honeybee (Apis mellifera L.), Evolution 43 (1989) 794-802.

[17] Medellin M.S., Campos L.E., Campos N. Gonzalez A.J.A., Camara G.V., Meliponicultura Maya: perspectivas para su sostenibilidad, Rep. sostenibilidad Maya 2, 1991, p. 67.

[18] Moritz R.F.A., Meusel M.J., Mitochondrial gene frequencies in Africanized honey bees (Apis mellifera L.): theoretical model and empirical evidence, J. Evol. Biol. 5 (1992) 71-81.

[19] Moritz R.F.A., Cornuet J.M., Kryger P., Garnery L., Hepburn H.R., Mitochondrial DNA variability in South African honeybees (Apis mellifera L.), Apidologie 25 (1994) 169-178.

[20] Nunamaker R.A., Wilson W.T., Haley B.E., Electrophoretic detection of Africanized honey bees (Apis mellifera scutellata L.) in Guatemala and Mexico based on malate dehidrogenase allozyme patterns, J. Kans. Entomol. Soc. 57 (1985) 622-631.

[21] Page R.E., Neotropical African bees, Nature 339 (1989) 181-182.

[22] Quezada-Euán J.J.G., Hinsull S.M., Evidence of continued European morphometrics and mtDNA in feral colonies of honey bees (Apis mellifera) from the Yucatan Península, Mexico, J. Apic. Res. 34 (1995) 161-166.

[23] Quezada-Euán J.J.G., May-Itzá W. de J., Características morfométricas, poblacionales y parasitosis de colonias silvestres de Apis mellifera (Hymenoptera: Apidae) en Yucatán, México, Folia Entomol. Mex. 97 (1996) 1-19.

[24] Quezada-Euán J.J.G., Medina L.M., Hybridization between European and Africanized honey- bees in tropical Yucatan, Mexico. I. Morphometric changes in feral and managed colonies, Apidologie 29 (1998) 555-568.

[25] Quezada-Euán J.J.G., Paxton R.J., Rapid intergenerational changes in morphology and defensive behaviour in colonies of Africanized and European honeybees (Apis mellifera) from tropical Yucatan, Mexico, J. Apic. Res. 38 (1998) 93-104.

[26] Quezada-Euán J.J.G., Echazarreta C.M., Paxton R.J., The distribution and range expansion of Africanized honey bees (Apis mellifera) in the state of Yucatan, Mexico, J. Apic. Res. 35 (1996) 85-95.

[27] Ratnieks F.L.W., Africanized bees: natural selection for colonizing ability, in: Spivak M., Fletcher D.J.C., Breed M.D. (Eds.), The 'African' Honey Bee, Westview Press. Boulder, CO, USA, 1991, pp. 119-136.

[28] Rinderer T.E., Hellmich R.L., The process of Africanization, in: Spivak M., Fletcher D.J.C. Breed M.D. (Eds.), Westview Press. Boulder, CO, USA, 1991, pp. 95-118.

[29] Rinderer T.E., Stelszer J.A., Oldroyd B.P., Buco S.M., Rubink W.L., Hybridization between European and Africanized honey bees in the neotropical Yucatan Península, Science 253 (1991) 309-311.

[30] Rinderer T.E., Buco S.M., Rubink W.L., Daly H.V., Stelszer J.A., Riggio R.M., Baptista F.C., Morphometric identification of Africanized and European honey bees using large reference populations, Apidologie 24 (1993) 569-585.

[31] Rinderer T.E., Oldroyd B.P., Sheppard W.S., Africanized bees in the US, Sci. Am. 269 (1993) 52-58.

[32] Saiki R.K., Gelfand D.H., Stoffel S., Scharff S.J., Higuchi R., Horn G.T., Mullis K.B., Erlich H.A., Primer-directed enzymatic amplification of DNA with a thermostable DNA polymerase, Science 239 (1988) 487-491.

[33] Sheppard W.S., Soares A.E.E., DeJong D., Shimanuki H., Hybrid status of honey bee populations near the historic origin of Africanization in Brazil, Apidologie 22 (1991) 643-652.

[34] Smith D.R., African bees in the Americas: insights from biogeography and genetics, Trends Ecol. Evol. 6 (1991) 17-21.

[35] Smith D.R., Taylor O.R., Brown W.M., Neotropical Africanized honey bees have African mitochondrial DNA, Nature 339 (1989) 213-215.

[36] Taylor O.R., African bees: potential impact in the United States, Bull. Entomol. Soc. Am. 31 (1985) 15-24. 